\title{
Poor Oral Health as a Determinant of Malnutrition and Sarcopenia
}

\author{
Domenico Azzolino ${ }^{1,2, *,+} \mathbb{0}$, Pier Carmine Passarelli ${ }^{3,+}{ }^{,}$, Paolo De Angelis ${ }^{3}$, \\ Giovan Battista Piccirillo ${ }^{3}$, Antonio D'Addona $^{3}$ and Matteo Cesari ${ }^{1,2}$ \\ 1 Geriatric Unit, Fondazione IRCCS Ca' Granda Ospedale Maggiore Policlinico, 20122 Milan, Italy; \\ matteo.cesari@unimi.it \\ 2 Department of Clinical Sciences and Community Health, University of Milan, 20122 Milan, Italy \\ 3 Department of Head and Neck, Oral Surgery and Implantology Unit, Institute of Clinical Dentistry, \\ Catholic University of Sacred Hearth, Fondazione Policlinico Universitario Gemelli, 00168 Rome, Italy; \\ piercarminepassarelli@hotmail.it (P.C.P.); dr.paolodeangelis@gmail.com (P.D.A.); \\ giovanbpiccirillo@gmail.com (G.B.P.); antonio.daddona@unicatt.it (A.D.) \\ * Correspondence: domenico.azzolino@policlinico.mi.it \\ + These authors contributed equally to this work.
}

Received: 7 November 2019; Accepted: 27 November 2019; Published: 29 November 2019

\begin{abstract}
Aging is accompanied by profound changes in many physiological functions, leading to a decreased ability to cope with stressors. Many changes are subtle, but can negatively affect nutrient intake, leading to overt malnutrition. Poor oral health may affect food selection and nutrient intake, leading to malnutrition and, consequently, to frailty and sarcopenia. On the other hand, it has been highlighted that sarcopenia is a whole-body process also affecting muscles dedicated to chewing and swallowing. Hence, muscle decline of these muscle groups may also have a negative impact on nutrient intake, increasing the risk for malnutrition. The interplay between oral diseases and malnutrition with frailty and sarcopenia may be explained through biological and environmental factors that are linked to the common burden of inflammation and oxidative stress. The presence of oral problems, alone or in combination with sarcopenia, may thus represent the biological substratum of the disabling cascade experienced by many frail individuals. A multimodal and multidisciplinary approach, including personalized dietary counselling and oral health care, may thus be helpful to better manage the complexity of older people. Furthermore, preventive strategies applied throughout the lifetime could help to preserve both oral and muscle function later in life. Here, we provide an overview on the relevance of poor oral health as a determinant of malnutrition and sarcopenia.
\end{abstract}

Keywords: sarcopenia; nutrition; oral health; older people; malnutrition; swallowing; life course approach

\section{Introduction}

Advancing age is characterized by a progressive decline in multiple physiological functions, leading to an increased vulnerability to stressors and augmented risk of adverse outcomes [1-3]. During the aging process, several factors may affect body shape from both clinical and functional perspectives. Reduction in smell and taste senses, poor appetite (the so-called "anorexia of aging"), and decreased energy expenditure may all contribute to poor nutrition. Moreover, illnesses, medications, as well as poor oral health (for example, due to teeth loss and poorly fitting dentures) can exacerbate anorexia [4-6]. Nutritional status among older people may be also influenced by living or eating alone, poor financial status, dismobility, and decreased ability to shop or prepare meals $[7,8]$. Psychosocial factors including loneliness, sleep disorders, dementia, and depression are also recognized to have a negative impact on the dietary intake of older subjects [9]. 
Furthermore, with aging, there is a progressive loss in muscle mass and strength, whereas fat mass and fat infiltration of muscle increase [10,11]. Sarcopenia is the term, introduced for the first time in 1988 by Irwin Rosenberg, to indicate the pathologic reduction in muscle mass and strength leading to a poor function $[12,13]$. Interestingly, in recent years, it has been highlighted that sarcopenia is not limited to lower limbs, but is a whole-body process [14-16], also affecting the muscles devoted to chewing and swallowing $[10,17]$, with a negative impact on food intake. In fact, atrophy of muscles critical for the respiratory and swallowing functions has been reported [14,18-22].

The variety of dental problems experienced by older people can result in chewing difficulties determining changes in food selection, thus leading to malnutrition and consequently to frailty [23] and sarcopenia $[10,23]$. Poor oral status may also predispose one to a chronic low-grade systemic inflammation through periodontal disease [24,25], which has an increased prevalence in those who are not able to perform the daily oral hygiene procedures [26], and it is a well-known risk factor in the pathogenesis of frailty [27] and sarcopenia [28]. Furthermore, periodontal disease has been associated with faster decline in handgrip strength [29], and recent studies showed an association between chewing difficulties and frailty [24].

Therefore, a hypothetical triangle oral status-nutrition-sarcopenia, exposing the older person to the frailty disabling cascade, may be suggested, as seen in Figure 1.

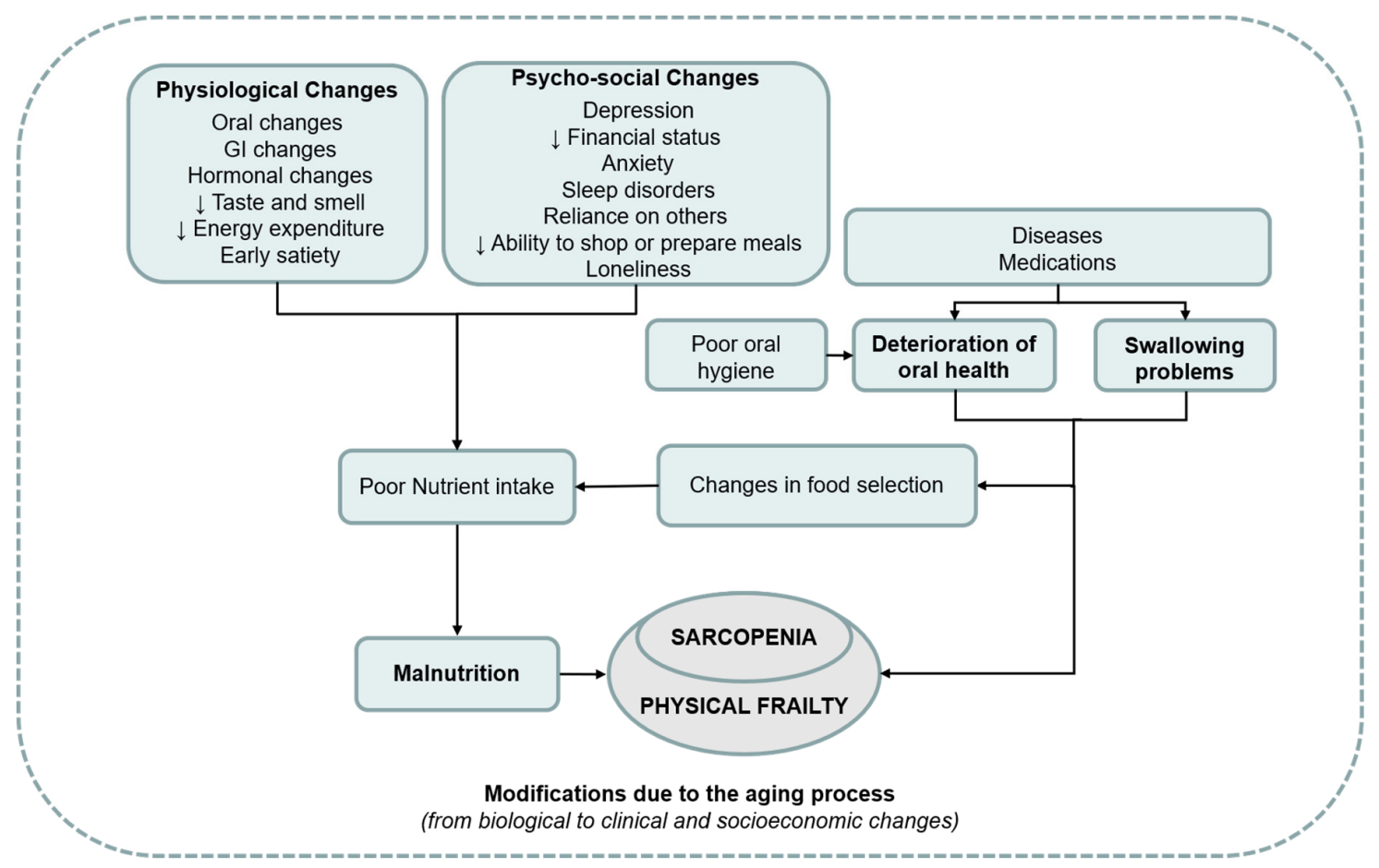

Figure 1. Overview of the interplay between poor oral status, malnutrition, and sarcopenia. GI-gastrointestinal.

\section{Oral Changes with Aging}

Poor oral health is not an inevitable part of aging since good care throughout the life course can result in the maintenance of functional teeth later in life [24]. Throughout a lifetime, the oral cavity experiences a variety of physiological modifications, such as enamel changes, fractures lines and stains, as well as dentin exposure and darkening of the tooth. At the same time, in the inner part of the tooth, several changes, such as the deposition of secondary dentin reducing the size of the pulp chamber and canals, may also occur [30]. Furthermore, in older people, tooth wear is frequently observed, affecting more than $85 \%$ of all the teeth groups in both the mandible and maxilla [31]. Additionally, a loss in terms of elastic fibers in the connective tissue has been documented and, subsequently, the oral mucosa becomes less resilient [32]. 
However, older people, especially those who are institutionalized or with limited financial resources, may experience problems to access oral care. Furthermore, it has been documented that older people frequently have difficulty expressing complaints and assign low priority to oral health until dental problems become intolerable [33]. Oral problems among older people have been implicated in a high prevalence of tooth loss, dental caries, periodontal disease, xerostomia, and oral precancer/cancer lesions [34]. Periodontitis and dental caries are very common diseases, especially in older people, and are considered the main cause of tooth loss [35].

Around the age of 70, there is also a peak of root/cementum caries, as a result of both tooth retention and major exposure of these surfaces following periodontal support loss. Moreover, older people are at higher risk of periodontitis since it is a cumulative disease, especially with regard to the multirooted teeth [36].

\subsection{Edentulism}

Edentulism is a pathological condition characterized by multiple missing teeth; it can be partial or total. The etiology of tooth loss includes factors such as predisposition, diet, hormonal status, coexisting diseases, hygiene habits, and use of dental clinics. Additionally, edentulism may result from an unsuccessful periodontal treatment or important carious lesions [37,38]. Dental disease and loss of teeth are not part of normal aging, but if this occurs, it is probably a result of neglected oral hygiene and/or an inadequate treatment $[39,40]$. Edentulism is exacerbated when masticatory function is not restored with dental prostheses [41]. Tooth loss affects the individual ability to chew determining an alteration of food choices [42]. Indeed, edentulous people are at greater risk of malnutrition than dentate or partially dentate individuals [43], and, consequently, with an increased susceptibility to sarcopenia and frailty [25]. Tooth loss is also a risk factor for disability, since it impedes self-sufficiency and worsens the quality of life [42].

\subsection{Dry Mouth}

Saliva is pivotal for bolus formation and consequently is also related to the sensory and textural experience. Xerostomia is a clinical condition characterized by an excessive sensation of dryness in the mouth, which is not necessarily linked to salivary gland hypofunction [30,44]. Xerostomia is estimated to affect $25-50 \%$ of older individuals [45]. Etiologic factors include polypharmacy (especially with antihypertensives, antidepressants, and antipsychotics) [46], diseases, poor general health, female sex, and older age $[47,48]$. Furthermore, radiation for head and neck cancers can damage salivary glands, leading to permanent xerostomia [49]. With aging, there is also a reduced salivary flow in salivary glands, which cannot be explained only on the basis of medications [50]. In fact, salivary hypofunction and xerostomia are two distinct constructs that are frequently improperly used interchangeably [33].

However, it has been reported that nearly one third of older adults complaining of xerostomia do not present any reduction of the salivary flow or saliva secretion. This suggests a psychological component may be involved when reporting the symptom [30]. Nonetheless, hyposalivation may seriously compromise chewing function and early digestive process. A reduced quantity of saliva can, in fact, affect the preparation of the alimentary bolus and the swallowing [51].

\subsection{Periodontal Disease}

Periodontitis is described as a chronic inflammatory disease that affects the supporting tissues of the teeth, leading to a progressive destruction of the periodontium [52]. It can also cause mobility and displacement of the remaining teeth and is often linked to difficulty in chewing. Prevalence of periodontal disease, considering a periodontal index score of 4 (deep pockets), ranges from approximately $5 \%$ to $70 \%$ among older people [53]. Periodontitis is a cumulative disease; therefore, it becomes increasingly severe as the person ages [30]. Poor oral hygiene is a critical determinant of periodontitis since it leads to the formation of dental plaque containing microorganisms [54]. Systemic risk factors for periodontal disease also include other behaviors, such as smoking, medical conditions (i.e., 
poorly controlled diabetes, obesity, stress, osteopenia), and inadequate dietary consumption of calcium and vitamin D [55]. Since periodontitis share some characteristics with other systemic inflammatory diseases, a relationship between periodontitis and other inflammatory pathologies (i.e., diabetes, cardiovascular diseases, adverse pregnancy outcomes, and rheumatoid arthritis) has been proposed [56].

In recent years, the role of the diet in periodontitis has been highlighted. To date, it has been documented that a diet poor in fruit and vegetables and therefore in micronutrients may lead to a greater inflammatory response of periodontal tissues that support the tooth. Interestingly, a recent systematic review of the relationship between dietary intake and periodontal health in community-dwelling older adults, reported positive associations between periodontal disease and lower intakes of docosahexaenoic acid, vitamin $C$, vitamin $E, \beta$-carotene, milk, fermented dairy products, dietary fiber, fruits and vegetables, and higher intakes of omega-6/omega-3 ratio and saturated fatty acids [57]. Additionally, micronutrient deficiencies can negatively affect healing following periodontal surgery [58]. At the same time, the loss of dental elements due to periodontitis can negatively affect the nutritional status of the patient, resulting in a discomfort during chewing and leading to a selection of soft and easy-to-chew foods.

\subsection{Dental Caries}

Dental caries is a multifactorial infectious disease characterized by the demineralization and destruction of the dental substance: enamel, in fact, is susceptible to acid dissolution over time. The pathological changes of the dental structure may have serious consequences, ultimately leading to the breakdown of the teeth themselves [59]. The prevalence of dental caries varies between $20 \%$ and $60 \%$ in community-dwelling older people and $60 \%$ and $80 \%$ in care home settings [60-64]. Various predisposing conditions to dental caries have been reported, including carbohydrate (especially simple sugars) consumption, diabetes, and poor socioeconomic conditions [60,65-68].

With increasing age, people may experience physical and cognitive decline, which may result in poor oral hygiene, leading to an increased incidence of caries. Over time, small lesions already filled can need a larger dental restoration, that can lead to a tooth fracture or an endodontic treatment [30]. Endodontic therapy (also known as root canal treatment) is a necessary procedure in case of inflamed or infected dental pulp. It consists in the removal of the pulp, both in the coronal and radicular part of the tooth, and in its replacement with a gutta-percha permanent filling (a substance of vegetable origin such as natural rubber). Xerostomia is closely related to a higher risk for developing caries since loss of saliva may lead to an increased acidity of the mouth. This leads to different situations that may contribute to the development of the dental caries: the proliferation of bacteria, the loss of minerals from the tooth surfaces, and the loss of lubrication [69].

\subsection{Impact of Oral Health on Nutritional Status}

Nutrition is a key modulator of health in older persons. Inadequate intake of nutrients is a well-known contributing factor in the progression of many diseases. This also has a significant impact in the complex etiology of sarcopenia and frailty [70-72]. Due to a decline in many functions, including poor oral status, dietary intake is often compromised in older people and the risk of malnutrition is increased. Particularly, acute and chronic illnesses and medications as well as poor dentition can exacerbate anorexia $[5,70,73]$. Oral problems in older individuals are associated with modifications in food selection and, therefore, in nutrient intake [25]. Deterioration of oral health can ultimately lead to the development of chronic conditions such as diabetes [74] and cardiovascular problems [75-77]. Masticatory performance is affected by the number of teeth in functional occlusion [78-80], the maximal biting force [81,82], denture wearing [83] and xerostomia [84]. The functional occlusion during mandibular closure is provided by the even and simultaneous contact of all remaining teeth (at least 20 with 10 contiguous teeth in each arch) [85].

Tooth loss has been implicated in the reduction of chewing ability and in difficulties in bolus formation [86]. To date, it has been reported that as number of remaining teeth decrease, the bolus 
size increases leading to a dysfunctional swallowing [87]. Edentulous individuals, even when using well-made dentures, may experience more chewing difficulties than dentate people [88]. Therefore, they may be considered as the group more prone to changing their diet $[89,90]$. Older people who experience dental problems frequently avoid harder foods such as meats, fruits, and vegetables which are typically major sources of proteins, fiber, vitamins, and minerals $[41,88,91]$. The lack of these latter key nutrients may expose older individuals to an increased risk for malnutrition, frailty, and sarcopenia [24,92]. In addition, it is well established that micronutrient deficiencies, even subtle, may lead to oxidative stress and consequently to inflammation. Therefore, these processes can further exacerbate sarcopenia and frailty and become a clear risk factor for periodontitis. Nutritional deficiencies may also negatively affect the mineralization process, increasing the susceptibility to dental caries [93]. Furthermore, undernutrition can exacerbate the severity of oral infections [94]. Indeed, with advancing age, people show a tendency to select soft foods due to difficulty and fatigue of chewing [10,95]. However, these latter are frequently processed foods that are high in fat and sugar and with a poor content of vitamins and minerals, leading to fat deposition, oxidative stress, inflammation, and, consequently, increased risk of cardiovascular disease and metabolic syndrome [88,95-97]. In fact, it is well established that obesity leads to chronic low-grade inflammation, increasing the susceptibility to dental caries, periodontal disease, and tooth loss [98]. The excess of energy is stored in adipocytes and leads to both hypertrophy and hyperplasia, resulting in an abnormal adipocyte function. This may increase mitochondrial stress and altered endoplasmatic reticulum function. Furthermore, adipocyte-associated inflammatory macrophages can also induce oxidative stress [99]. On the other hand, it is widely recognized that an excessive consumption of simple sugars is a major risk factor for dental caries [100,101].

Large epidemiological studies, such as the UK National Diet and Nutrition Survey (NDNS) [102] and the US National Health and Nutritional Examination Surveys (NHANES) [103,104], reported an association between poor dental status and inadequate dietary intake in older people. In particular, they reported that edentulous subjects, with and without prosthesis, consumed less fruits and vegetables. Moreover, decreased protein and micronutrient intake, together with increased carbohydrate consumption, has been reported in people with less than 21 teeth [104].

\section{Sarcopenia and Oral Status}

Sarcopenia, defined as the progressive and accelerated loss of muscle mass and function, is a major determinant of several adverse outcomes including frailty, disability, and mortality [13,105]. Although sarcopenia is a condition commonly observed with the aging process, it can also occur earlier in life [106]. Since 2016, sarcopenia has been recognized as an independent condition with an International Classification of Disease, 10th Revision, Clinical Modification (ICD-10-CM) Diagnosis Code [107]. Recently, the European Working Group on Sarcopenia in Older People (EWGSOP) [106] updated their consensus on definition and diagnosis (EWGSOP2). In this revised consensus, low muscle strength is considered a key characteristic of sarcopenia, and poor physical performance is identified as indicative of severe sarcopenia. Moreover, EWGSOP2 have recommended specific cut-off points to identify and characterize the sarcopenic condition, and provide an algorithm that can be used for case-finding.

Sarcopenia has a complex multifactorial pathogenesis, which involves lifestyle habits (i.e., malnutrition, physical inactivity), disease triggers, and age-dependent biological changes (i.e., chronic inflammation, mitochondrial abnormalities, loss of neuromuscular junctions, reduced satellite cell numbers, hormonal alterations) $[108,109]$. Sarcopenia is a whole-body process, affecting not only lower extremities, but also muscles dedicated to breathing, mastication, and swallowing [14,18-22]. In particular, swallowing is a complex mechanism involving several head and neck muscles simultaneously and in conjunction to coordinate the entire process [110]. Several age-related changes, such as as reduction of tissue elasticity, changes of the head and neck anatomy, reduced oral and pharyngeal sensitivity, and impaired dental status, may contribute to different degrees to a subtle swallowing impairment, the so called "presbyphagia". It is usually an asymptomatic condition in which swallowing function is preserved, but tends to slowly worsen as the aging process advances $[16,111]$. Presbyphagia may increase the risk 
of dysphagia and aspiration in older people, especially during acute illnesses and other stressors [112]. Moreover, reductions in muscle mass of the geniohyoid, pterygoid, masseter, tongue, and pharyngeal muscles have been documented in older individuals [20,113-115]. Several authors also reported a decline in the strength of the swallowing muscles with aging or sarcopenia [116]. Maximal tongue strength decreases with aging [116-119], and there is some evidence that aging leads to a decreased jaw-opening force in older men. Several authors also reported an association between tongue strength and handgrip strength [120,121]. A decrease in tongue strength has been associated with a decline of activities of daily living [122], and a reduced tongue thickness has been noted in people with low body weight [20].

Lip function is also important for feeding. In fact, poor lip muscle closure may cause leakage through the corners of the mouth [123]. Additionally, decreased lip strength has been suggested to occur due to sarcopenia and to be related to difficulties in eating and drinking (i.e., dysphagia) [117]. Lip force has been associated with hand grip strength and lip pendency has been associated with aging $[117,124]$.

Indeed, since it has been shown that skeletal muscle mass and strength decline may affect both swallowing and general muscle groups, a new condition, called "sarcopenic dysphagia" has been coined $[22,124,125]$. Swallowing muscles are characterized by a high percentage of type II fibers, which are more easily affected by malnutrition and sarcopenia than type I muscle fibers [22]. However, some cranial muscles, including the jaw-closers, are very different in fiber-type composition than other skeletal muscle groups (i.e., limbs or abdomen). For instance, the masseter muscle, which originates from the zygomatic arch, contains both type I and type II fibers, but shows a predominance of type I muscle fibers, which are more strongly affected by inactivity rather than aging [126,127]. Given that the meal texture of older people frequently becomes softer, less power of tongue movement and of masseter muscle is required, which may result in decreased activity of these muscles.

Interestingly, poor oral health may predispose one to a chronic low-grade inflammatory state through periodontal disease, which is a well-known risk factor for frailty and sarcopenia $[25,128,129]$. In fact, the detrimental effects of periodontitis are not confined solely to the oral cavity, but extend systemically, leading to metabolic alterations [130], including insulin resistance [131], diabetes [131,132], arthritis [133], and heart disease [134]. Furthermore, alterations in mitochondrial function leading to oxidative stress through the production of reactive oxygen species (ROS) have also been reported to mediate both oral and systemic pathologies (i.e., sarcopenia) [108,135-137]. Given their regulatory role as signaling molecules in autophagy, it has been speculated that elevated ROS production in periodontal disease could lead to autophagic alterations [138]. Bullon et al. [139] found high levels of mitochondrial-derived ROS, accompanied by mitochondrial dysfunction in peripheral blood mononuclear cells from patients with periodontitis. Moreover, oral gingiva seems to be highly responsive to the lipopolysaccharides (LPS), which are bacterial endotoxins prevalent in periodontal disease. In fact, gingival fibroblasts, which play an important role in remodeling periodontal soft tissues, may directly interact with LPS. In particular, LPS from Porphyromonas gingivalis enhances the production of inflammatory cytokines [140]. Porphyromonas gingivalis has been found to be responsible for high mitochondrial ROS and coenzyme Q10 levels, and for mitochondrial dysfunction, given its influence on the amount of respiratory chain complex I and III [138,139]. Indeed, LPS-mediated mitochondrial dysfunction could explain the oxidative stress onset in patients with periodontitis. Furthermore, Hamalainen et al. [29] reported an association between periodontitis and quicker declines in handgrip strength.

On the other hand, as discussed in the previous section, the variety of dental problems experienced by older people can lead to a decline in general health through poor nutrient intake, pain, and low quality of life [25]. Poor oral status has been reported to affect $71 \%$ of patients in rehabilitation settings [141] and $91 \%$ of people in acute-care hospitals [142], and has been associated with malnutrition, dysphagia, and reduced activities of daily living [17]. Hence, poor oral status may lead to sarcopenia through poor nutrient intake. Moreover, inflammation further contributes to malnutrition through various mechanisms, such as anorexia, decreased nutrient intake, altered metabolism (i.e., elevation 
of resting energy expenditure), and increased muscle catabolism [143]. Chronic inflammation is a common underlying factor, not only in the etiology of sarcopenia, but also for frailty. In fact, sarcopenia and frailty are closely related and show a remarkable overlap especially in the physical function domain [144-146]. The presence of oral problems, alone or in combination with sarcopenia, may thus represent the biological substratum of the disabling cascade experienced by many frail individuals.

\section{Interventions}

The management of older people should be multimodal and multidisciplinary, especially for those with or at risk of malnutrition [147], in order to improve different conditions (i.e., oral problems and sarcopenia). From a practical point of view, comprehensive geriatric assessment (CGA) is the multidimensional, interdisciplinary diagnostic and therapeutic process aimed at determining the medical, psychological, and functional problems of older people. The CGA's objective is the development of a coordinated and integrated plan for treatment and follow-up in order to maximize overall health with aging [148]. To date, increasing evidence suggests that prosthodontic treatment in combination with personalized dietary counselling may improve the nutritional status of patients [51]. Here, we provide an overview on the management of oral problems, malnutrition, and sarcopenia.

\subsection{Oral Management}

The stomatognathic system is very vulnerable over time, but with special care, it can be preserved throughout the lifetime [30]. Nevertheless, one of the major challenges in providing both restorative and preventive care for older adults is to check dental status on a regular basis [34]. Prevention is pivotal to detecting oral disease as soon as possible and requires regular patient contact. However, since it has been reported that older people frequently fail to achieve a good oral hygiene, both patients and caregivers should be made more aware about the importance to check dental status as well as oral hygiene.

The oral health-care professionals should develop a personalized program, in order to prevent all the problems related to the aging process. In some cases, it is difficult to provide dental care in the hospital setting in a short time, since in many countries there are long waiting lists (especially in publicly funded hospitals) [149]. Therefore, private dentists also need better awareness concerning the complexity of older people. There is, first and foremost, a need to understand the level of dependency, the medical condition, and the physical or cognitive impairment of the patient. Secondly, it is important to establish an oral healthcare plan that includes both professional and self-care elements [150].

The oral management of older people usually involves different aspects:

(1) For the teeth affected by carious lesions, it must be recommended that prompt treatment be provided in order to prevent tooth loss. It would be equally appropriate for endodontic treatments for teeth with endodontic problems.

(2) It is very important to monitor the periodontal status of the older patient and to provide a proper treatment plan, such as modification of general health-risk factors and oral health-specific risk factors, but professional hygiene or surgical procedures may also be necessary.

(3) Prosthetic rehabilitation of the edentulous patient may help to prevent malnutrition [151] since it restores the chewing function.

(4) In order to prevent problems related to the xerostomia and reduce exacerbation of carious lesions, it may be helpful to treat with saliva substitutes.

\subsection{Nutritional Interventions}

As discussed above, nutrition is an important determinant of health in older people. Thereby, it is pivotal to provide adequate amounts of energy, proteins, fluid, and micronutrients in order to prevent or treat excess or deficiencies, and therefore improve several health-related outcomes in terms of morbidity and mortality. A personalized approach is pivotal in order to respect individual 
preferences, needs, and to increase compliance to the diet. Nutritional status should be assessed before each intervention, and the amount of energy and proteins should be individually adjusted with regard to nutritional status, physical activity level, disease status, and tolerance [152]. The European Society for Clinical Nutrition and Metabolism (ESPEN) [152], in its guidelines on clinical nutrition and hydration in geriatrics, recommends a guiding value for energy intake of $30 \mathrm{kcal} / \mathrm{kg}$ of body weight/day. However, as stated above, it should be adapted individually. Both ESPEN [153] and the PROT-AGE study group [147] recommend providing a protein intake of at least $1.0 \mathrm{~g} / \mathrm{kg}$ body weight/day in older people to maintain muscle mass, increasing the intake up to $1.2-1.5 \mathrm{~g} / \mathrm{kg}$ body weight/day in presence of acute or chronic illness. Additionally, it seems that the per-meal anabolic threshold of protein intake is higher in older individuals (i.e., 25 to $30 \mathrm{~g}$ protein/meal, containing about 2.5 to $2.8 \mathrm{~g}$ leucine) than young adults [147]. However, since older people may experience difficulty of ingesting large amounts of proteins in a single meal, supplementation should be considered. Since serum vitamin D levels decline gradually with aging $[154,155]$ and have been associated with reduced muscle mass and strength, supplementation should thus be considered in those who are deficient.

Food texture should be adapted depending on the chewing and swallowing condition in order to avoid choking risk [10]. Harder foods may be modified to soft consistencies (i.e., bite-sized, minced, pureed) requiring little chewing, as well as liquids, which may be thickened to render the swallowing process slower and safer $[10,156,157]$. Controlling the intake of simple sugars is pivotal to prevent both dental caries [101] and metabolic complications [158]. World Health Organization recommends to limit the intake of free sugars to less than $10 \%$ of total energy intake to minimize the risk of dental caries [159].

Fruit and vegetables are major sources of minerals and vitamins with antioxidant properties; therefore, their consumption should be promoted both for oral and general health. It has been documented that excessive antioxidant supplementation could compromise both the mechanism of adaption to exercise and have even pro-oxidant effects. Thus, supplementation in people who are not deficient should be regarded carefully [160]. Dietary consumption of fatty fish (i.e., salmon, mackerel, herring, lake trout, sardines, albacore tuna, and their oils), which are a major source of omega-3 fatty acids, has been associated with a greater fat-free mass [161]. Given their antioxidant role, omega-3 fatty acid supplementation has been suggested to improve inflammatory status both in periodontal disease [162] and sarcopenia [163]. However, more studies are needed to further elucidate the exact time and dosage of supplementation as well as long term effects [164]. Nevertheless, consumption of foods rich in omega-3, such as as fatty fish, should be promoted.

\subsection{Exercise and Rehabilitative Strategies}

Physical inactivity is considered one of the main causes of sarcopenia [165] because it determines a resistance to muscle anabolic stimuli [166]. Moreover, it has been proposed that physically inactive individuals may have a greater risk of periodontal disease [167]. In particular, resistance training seems to be the most effective type of exercise to counteract sarcopenia [168]. Furthermore, since sarcopenia is a systemic process [15,21], it has been recommended to perform a holistic training involving all muscle groups [15]. In fact, it has been documented that both masticatory and swallowing functions can be improved through muscle-strengthening exercises [169,170]. Several studies reported enhancements in subjective chewing ability, swallowing function, salivation, relief of oral dryness, and oral-health quality of life. Indeed, the synergistic effect of nutritional interventions coupled with physical exercise may improve both muscle [164] and oral health [167]. Recently, Kim et al. [171] reported an improvement in oral function following an exercise program which included stretching of the lip, tongue, cheek, masticatory muscle exercise, and swallowing movements. Several studies have been focused on swallowing rehabilitation. To date, a positive effect of expiratory muscle resistance training has been documented in improving suprahyoid muscle activity $[172,173]$. Furthermore, head lift exercises showed a beneficial impact on swallowing movements [174,175], and tongue strengthening exercises have been reported to enhance tongue strength $[176,177]$. Yeates et al. [178] demonstrated that isometric tongue strength exercises and tongue pressure accuracy tasks improved isometric tongue 
strength, tongue pressure generation accuracy, bolus control, and dietary intake by mouth. It has also been reported that tongue exercises prevented general sarcopenia $[178,179]$. Indeed, swallowing muscles training, despite its focus on swallowing function, may exert its beneficial effects systemically.

\section{Conclusions}

Aging is characterized by a progressive loss of physiological integrity, leading to a decline in many functions and increased vulnerability to stressors. Many changes in masticatory and swallowing function are subtle but can amplify disease processes seen with aging. Nevertheless, it is often difficult to clearly distinguish the effects of diseases from the underlying age-related modifications. Several stressors, including oral problems, may therefore negatively impact on the increasingly weak homeostatic reserves of older individuals. As a healthy diet may have a systemic beneficial effect, oral care also shows an important role in maintaining and improving not only oral health, but also general health and well-being.

Overall, severe tooth loss, as well as swallowing and masticatory problems, partly contribute to restricted dietary choices and poor nutritional status of older adults, leading to frailty and sarcopenia. On the other hand, oral diseases might be influenced both by frailty and sarcopenia, probably through biological and environmental factors that are linked to the common burden of inflammation and oxidative stress.

A multidisciplinary intervention of dental professionals, geriatricians, nutritionists, and dietitians may help to provide better care and preserve the functional status of older people. Increasing evidence also suggests that oral care, when offered with personalized nutritional advice, may improve the nutritional status of patients. A life course approach to prevention at a younger age, including diet optimization and oral preventive care, as well as physical activity, may help in preserving both oral and muscle function later in life.

Author Contributions: D.A. and P.C.P. equally contributed to conceptualizing and writing the manuscript. P.D.A., G.B.P., A.D. and M.C. edited and revised manuscript. D.A., P.C.P., P.D.A., G.B.P., A.D. and M.C. approved the final version of manuscript.

Funding: This research received no external funding.

Conflicts of Interest: The authors declare no conflict of interest.

\section{References}

1. Bales, C.W.; Ritchie, C.S. Sarcopenia, weight loss, and nutritional frailty in the elderly. Annu. Rev. Nutr. 2002, 22, 309-323. [CrossRef]

2. Palmer, K.; Onder, G.; Cesari, M. The geriatric condition of frailty. Eur. J. Intern. Med. 2018, 56, 1-2. [CrossRef]

3. López-Otín, C.; Blasco, M.A.; Partridge, L.; Serrano, M.; Kroemer, G. The hallmarks of aging. Cell 2013, 153, 1194-1217. [CrossRef]

4. Leslie, W.; Hankey, C. Aging, Nutritional Status and Health. Healthcare 2015, 3, 648-658. [CrossRef]

5. Roberts, H.C.; Lim, S.E.R.; Cox, N.J.; Ibrahim, K. The Challenge of Managing Undernutrition in Older People with Frailty. Nutrients 2019, 11, 808. [CrossRef]

6. Hickson, M. Malnutrition and ageing. Postgrad. Med. J. 2006, 82, 2-8. [CrossRef]

7. Schilp, J.; Wijnhoven, H.A.H.; Deeg, D.J.H.; Visser, M. Early determinants for the development of undernutrition in an older general population: Longitudinal Aging Study Amsterdam. Br. J. Nutr. 2011, 106, 708-717. [CrossRef]

8. $\quad$ Locher, J.L.; Ritchie, C.S.; Roth, D.L.; Sen, B.; Vickers, K.S.; Vailas, L.I. Food choice among homebound older adults: Motivations and perceived barriers. J. Nutr. Health Aging 2009, 13, 659-664. [CrossRef]

9. Bloom, I.; Lawrence, W.; Barker, M.; Baird, J.; Dennison, E.; Sayer, A.A.; Cooper, C.; Robinson, S. What influences diet quality in older people? A qualitative study among community-dwelling older adults from the Hertfordshire Cohort Study, UK. Public Health Nutr. 2017, 20, 2685-2693. [CrossRef]

10. Cichero, J.A.Y. Age-Related Changes to Eating and Swallowing Impact Frailty: Aspiration, Choking Risk, Modified Food Texture and Autonomy of Choice. Geriatrics 2018, 3, 69. [CrossRef] 
11. Calvani, R.; Miccheli, A.; Landi, F.; Bossola, M.; Cesari, M.; Leeuwenburgh, C.; Sieber, C.C.; Bernabei, R.; Marzetti, E. Current nutritional recommendations and novel dietary strategies to manage sarcopenia. J. Frailty Aging 2013, 2, 38-53.

12. Rosenberg, I.H. Sarcopenia: Origins and clinical relevance. J. Nutr. 1997, 127 (Suppl. S5), 990S-991S. [CrossRef]

13. Cruz-Jentoft, A.J.; Landi, F. Sarcopenia. Clin. Med. 2014, 14, 183-186. [CrossRef]

14. Komatsu, R.; Okazaki, T.; Ebihara, S.; Kobayashi, M.; Tsukita, Y.; Nihei, M.; Sugiura, H.; Niu, K.; Ebihara, T.; Ichinose, M. Aspiration pneumonia induces muscle atrophy in the respiratory, skeletal, and swallowing systems. J. Cachexia Sarcopenia Muscle 2018, 9, 643-653. [CrossRef]

15. Beckwée, D.; Delaere, A.; Aelbrecht, S.; Baert, V.; Beaudart, C.; Bruyere, O.; de Saint-Hubert, M.; Bautmans, I. Exercise Interventions for the Prevention and Treatment of Sarcopenia. A Systematic Umbrella Review. J. Nutr. Health Aging 2019, 23, 494-502. [CrossRef]

16. Azzolino, D.; Damanti, S.; Bertagnoli, L.; Lucchi, T.; Cesari, M. Sarcopenia and swallowing disorders in older people. Aging. Clin. Exp. Res. 2019, 22, 1-7. [CrossRef]

17. Shiraishi, A.; Yoshimura, Y.; Wakabayashi, H.; Tsuji, Y. Prevalence of stroke-related sarcopenia and its association with poor oral status in post-acute stroke patients: Implications for oral sarcopenia. Clin. Nutr. 2018, 37, 204-207. [CrossRef]

18. Iee Shin, H.; Kim, D.-K.; Seo, K.M.; Kang, S.H.; Lee, S.Y.; Son, S. Relation Between Respiratory Muscle Strength and Skeletal Muscle Mass and Hand Grip Strength in the Healthy Elderly. Ann. Rehabil. Med. 2017, 41, 686-692. [CrossRef]

19. Fujishima, I.; Fujiu-Kurachi, M.; Arai, H.; Hyodo, M.; Kagaya, H.; Maeda, K.; Mori, T.; Nishioka, S.; Oshima, F.; Ogawa, S.; et al. Sarcopenia and dysphagia: Position paper by four professional organizations. Geriatr. Gerontol. Int. 2019, 19, 91-97. [CrossRef]

20. Tamura, F.; Kikutani, T.; Tohara, T.; Yoshida, M.; Yaegaki, K. Tongue thickness relates to nutritional status in the elderly. Dysphagia 2012, 27, 556-561. [CrossRef]

21. Cruz-Jentoft, A.J.; Sayer, A.A. Sarcopenia. Lancet 2019, 393, 2636-2646. [CrossRef]

22. Wakabayashi, H.; Sakuma, K. Rehabilitation nutrition for sarcopenia with disability: A combination of both rehabilitation and nutrition care management. J. Cachexia Sarcopenia Muscle 2014, 5, 269-277. [CrossRef] [PubMed]

23. Castrejón-Pérez, R.C.; Jiménez-Corona, A.; Bernabé, E.; Villa-Romero, A.R.; Arrivé, E.; Dartigues, J.-F.; Gutiérrez-Robledo, L.M.; Borges-Yáñez, S.A. Oral Disease and 3-Year Incidence of Frailty in Mexican Older Adults. J. Gerontol. Ser. A 2017, 72, 951-957. [CrossRef] [PubMed]

24. Woo, J.; Tong, C.; Yu, R. Chewing Difficulty Should be Included as a Geriatric Syndrome. Nutrients 2018, 10, 2019. Available online: https://www.ncbi.nlm.nih.gov/pmc/articles/PMC6315631/ (accessed on 11 October 2019). [CrossRef] [PubMed]

25. Castrejón-Pérez, R.C.; Borges-Yáñez, S.A.; Gutiérrez-Robledo, L.M.; Avila-Funes, J.A. Oral health conditions and frailty in Mexican community-dwelling elderly: A cross sectional analysis. BMC Public Health 2012, 12, 773. [CrossRef] [PubMed]

26. Lertpimonchai, A.; Rattanasiri, S.; Arj-Ong Vallibhakara, S.; Attia, J.; Thakkinstian, A. The association between oral hygiene and periodontitis: A systematic review and meta-analysis. Int. Dent. J. 2017, 67, 332-343. [CrossRef]

27. Dent, E.; Kowal, P.; Hoogendijk, E.O. Frailty measurement in research and clinical practice: A review. Eur. J. Intern. Med. 2016, 31, 3-10. [CrossRef]

28. Rolland, Y.; Czerwinski, S.; Abellan Van Kan, G.; Morley, J.E.; Cesari, M.; Onder, G.; Woo, J.; Baumgartner, R.; Pillard, F.; Boirie, Y.; et al. Sarcopenia: Its assessment, etiology, pathogenesis, consequences and future perspectives. J. Nutr. Health Aging 2008, 12, 433-450. [CrossRef]

29. Hämäläinen, P.; Rantanen, T.; Keskinen, M.; Meurman, J.H. Oral health status and change in handgrip strength over a 5-year period in 80-year-old people. Gerodontology 2004, 21, 155-160. [CrossRef]

30. Lamster, I.B.; Asadourian, L.; Del Carmen, T.; Friedman, P.K. The aging mouth: Differentiating normal aging from disease. Periodontol 2000 2016, 72, 96-107. [CrossRef]

31. Liu, B.; Zhang, M.; Chen, Y.; Yao, Y. Tooth wear in aging people: An investigation of the prevalence and the influential factors of incisal/occlusal tooth wear in northwest China. BMC Oral Health 2014, 14, 65. [CrossRef] [PubMed]

32. Klein, D.R. Oral soft tissue changes in geriatric patients. Bull. N. Y. Acad. Med. 1980, 56, 721-727. [PubMed]

33. MacEntee, M.I.; Donnelly, L.R. Oral health and the frailty syndrome. Periodontology 2000 2016, 72, $135-141$. [CrossRef] [PubMed] 
34. Razak, P.A.; Richard, K.M.J.; Thankachan, R.P.; Hafiz, K.A.A.; Kumar, K.N.; Sameer, K.M. Geriatric Oral Health: A Review Article. J. Int. Oral Health 2014, 6, 110-116. [PubMed]

35. Chapple, I.L.C.; Bouchard, P.; Cagetti, M.G.; Campus, G.; Carra, M.-C.; Cocco, F.; Nibali, L.; Hujoel, P.; Laine, M.L.; Lingstrom, P.; et al. Interaction of lifestyle, behaviour or systemic diseases with dental caries and periodontal diseases: Consensus report of group 2 of the joint EFP/ORCA workshop on the boundaries between caries and periodontal diseases. J. Clin. Periodontol. 2017, 44 (Suppl S18), S39-S51. [CrossRef]

36. Hirotomi, T.; Yoshihara, A.; Yano, M.; Ando, Y.; Miyazaki, H. Longitudinal study on periodontal conditions in healthy elderly people in Japan. Community Dent. Oral Epidemiol. 2002, 30, 409-417. [CrossRef] [PubMed]

37. Burt, B.A.; Ismail, A.I.; Morrison, E.C.; Beltran, E.D. Risk factors for tooth loss over a 28 -year period. J. Dent. Res. 1990, 69, 1126-1130. [CrossRef]

38. Bahrami, G.; Vaeth, M.; Kirkevang, L.-L.; Wenzel, A.; Isidor, F. Risk factors for tooth loss in an adult population: A radiographic study. J. Clin. Periodontol. 2008, 35, 1059-1065. [CrossRef]

39. Singh, K.A.; Brennan, D.S. Chewing disability in older adults attributable to tooth loss and other oral conditions. Gerodontology 2012, 29, 106-110. [CrossRef]

40. Zhang, Q.; Witter, D.J.; Bronkhorst, E.M.; Creugers, N.H. Chewing ability in an urban and rural population over 40 years in Shandong Province, China. Clin. Oral Investig. 2013, 17, 1425-1435. [CrossRef]

41. Gil-Montoya, J.A.; Ferreira de Mello, A.L.; Barrios, R.; Gonzalez-Moles, M.A.; Bravo, M. Oral health in the elderly patient and its impact on general well-being: A nonsystematic review. Clin. Interv. Aging 2015, 10, 461-467. [CrossRef] [PubMed]

42. Musacchio, E.; Perissinotto, E.; Binotto, P.; Sartori, L.; Silva-Netto, F.; Zambon, S.; Manzato, E.; Corti, M.C.; Baggio, G.; Crepaldi, G. Tooth loss in the elderly and its association with nutritional status, socio-economic and lifestyle factors. Acta Odontol. Scand. 2007, 65, 78-86. [CrossRef] [PubMed]

43. Felton, D.A. Complete Edentulism and Comorbid Diseases: An Update. J. Prosthodont. 2016, 25, 5-20. [CrossRef] [PubMed]

44. Xu, F.; Laguna, L.; Sarkar, A. Aging-related changes in quantity and quality of saliva: Where do we stand in our understanding? J. Texture Stud. 2019, 50, 27-35. [CrossRef]

45. Nagler, R.M. Salivary glands and the aging process: Mechanistic aspects, health-status and medicinal-efficacy monitoring. Biogerontology 2004, 5, 223-233. [CrossRef]

46. Scully, C. Drug effects on salivary glands: Dry mouth. Oral Dis. 2003, 9, 165-176. [CrossRef]

47. Singh, M.L.; Papas, A. Oral implications of polypharmacy in the elderly. Dent. Clin. 2014, 58, 783-796. [CrossRef]

48. Mortazavi, H.; Baharvand, M.; Movahhedian, A.; Mohammadi, M.; Khodadoustan, A. Xerostomia Due to Systemic Disease: A Review of 20 Conditions and Mechanisms. Ann. Med. Health Sci. Res. 2014, 4, 503-510.

49. Dumic, I.; Nordin, T.; Jecmenica, M.; Stojkovic Lalosevic, M.; Milosavljevic, T.; Milovanovic, T. Gastrointestinal Tract Disorders in Older Age. Can. J. Gastroenterol. Hepatol. 2019. Available online: https://www.hindawi. com/journals/cjgh/2019/6757524/ (accessed on 11 October 2019). [CrossRef]

50. Affoo, R.H.; Foley, N.; Garrick, R.; Siqueira, W.L.; Martin, R.E. Meta-Analysis of Salivary Flow Rates in Young and Older Adults. J. Am. Geriatr. Soc. 2015, 63, 2142-2151. [CrossRef]

51. Kossioni, A.E. The Association of Poor Oral Health Parameters with Malnutrition in Older Adults: A Review Considering the Potential Implications for Cognitive Impairment. Nutrients 2018, 10, 1709. [CrossRef] [PubMed]

52. Saini, R.; Marawar, P.P.; Shete, S.; Saini, S. Periodontitis, a true infection. J. Glob. Infect. Dis. 2009, 1, $149-150$. [CrossRef] [PubMed]

53. WHO. WHO Oral Health Country Area Profile Programe. Available online: https://www.who.int/oral_ health/databases/malmo/en/ (accessed on 11 October 2019).

54. Ashimoto, A.; Chen, C.; Bakker, I.; Slots, J. Polymerase chain reaction detection of 8 putative periodontal pathogens in subgingival plaque of gingivitis and advanced periodontitis lesions. Oral Microbiol. Immunol. 1996, 11, 266-273. [CrossRef] [PubMed]

55. Genco, R.J.; Borgnakke, W.S. Risk factors for periodontal disease. Periodontol 2000 2013, 62, 59-94. [CrossRef] [PubMed]

56. Hasturk, H.; Kantarci, A. Activation and Resolution of Periodontal Inflammation and Its Systemic Impact. Periodontol 2000 2015, 69, 255-273. [CrossRef] [PubMed]

57. O'Connor, J.-L.P.; Milledge, K.L.; O'Leary, F.; Cumming, R.; Eberhard, J.; Hirani, V. Poor dietary intake of nutrients and food groups are associated with increased risk of periodontal disease among community-dwelling older adults: A systematic literature review. Nutr. Rev. 2019. [CrossRef] 
58. Najeeb, S.; Zafar, M.S.; Khurshid, Z.; Zohaib, S.; Almas, K. The Role of Nutrition in Periodontal Health: An Update. Nutrients 2016, 8, 530. Available online: https://www.ncbi.nlm.nih.gov/pmc/articles/PMC5037517/ (accessed on 11 October 2019). [CrossRef]

59. Kunin, A.A.; Evdokimova, A.Y.; Moiseeva, N.S. Age-related differences of tooth enamel morphochemistry in health and dental caries. EPMA J. 2015, 6, 3. [CrossRef]

60. Avlund, K.; Holm-Pedersen, P.; Morse, D.E.; Viitanen, M.; Winblad, B. Tooth loss and caries prevalence in very old Swedish people: The relationship to cognitive function and functional ability. Gerodontology 2004, 21, 17-26. [CrossRef]

61. Banting, D.W.; Ellen, R.P.; Fillery, E.D. Prevalence of root surface caries among institutionalized older persons. Community Dent. Oral Epidemiol. 1980, 8, 84-88. [CrossRef]

62. Ellefsen, B.; Holm-Pedersen, P.; Morse, D.E.; Schroll, M.; Andersen, B.B.; Waldemar, G. Caries prevalence in older persons with and without dementia. J. Am. Geriatr. Soc. 2008, 56, 59-67. [CrossRef] [PubMed]

63. Fure, S.; Zickert, I. Prevalence of root surface caries in 55, 65, and 75-year-old Swedish individuals. Community Dent. Oral Epidemiol. 1990, 18, 100-105. [CrossRef] [PubMed]

64. Johanson, C.N.; Osterberg, T.; Steen, B.; Birkhed, D. Prevalence and incidence of dental caries and related risk factors in 70- to 76-year-olds. Acta Odontol. Scand. 2009, 67, 304-312. [CrossRef] [PubMed]

65. Wiktorsson, A.M.; Martinsson, T.; Zimmerman, M. Salivary levels of lactobacilli, buffer capacity and salivary flow rate related to caries activity among adults in communities with optimal and low water fluoride concentrations. Swed. Dent. J. 1992, 16, 231-237.

66. Lundberg, J.O. Nitrate transport in salivary glands with implications for NO homeostasis. Proc. Natl. Acad. Sci. USA 2012, 109, 13144-13145. [CrossRef]

67. Guivante-Nabet, C.; Berenholc, C.; Berdal, A. Caries activity and associated risk factors in elderly hospitalised population - 15-months follow-up in French institutions. Gerodontology 1999, 16, 47-58. [CrossRef]

68. Fure, S. Ten-year cross-sectional and incidence study of coronal and root caries and some related factors in elderly Swedish individuals. Gerodontology 2004, 21, 130-140. [CrossRef]

69. Su, N.; Marek, C.L.; Ching, V.; Grushka, M. Caries prevention for patients with dry mouth. J. Can. Dent. Assoc. 2011, 77, 1-8.

70. Morley, J.E. Anorexia of ageing: A key component in the pathogenesis of both sarcopenia and cachexia. J. Cachexia Sarcopenia Muscle 2017, 8, 523-526. [CrossRef]

71. Clegg, A.; Young, J.; Iliffe, S.; Rikkert, M.O.; Rockwood, K. Frailty in elderly people. Lancet 2013, 381, 752-762. [CrossRef]

72. Cruz-Jentoft, A.J.; Baeyens, J.P.; Bauer, J.M.; Boirie, Y.; Cederholm, T.; Landi, F.; Martin, F.C.; Michel, J.-P.; Rolland, Y.; Schneider, S.M.; et al. Sarcopenia: European consensus on definition and diagnosis: Report of the European Working Group on Sarcopenia in Older People. Age Ageing 2010, 39, 412-423. [CrossRef] [PubMed]

73. Agarwal, E.; Miller, M.; Yaxley, A.; Isenring, E. Malnutrition in the elderly: A narrative review. Maturitas 2013, 76, 296-302. [CrossRef] [PubMed]

74. Mealey, B.L.; Ocampo, G.L. Diabetes mellitus and periodontal disease. Periodontol 2000 2007, 44, 127-153. [CrossRef] [PubMed]

75. Karnoutsos, K.; Papastergiou, P.; Stefanidis, S.; Vakaloudi, A. Periodontitis as a risk factor for cardiovascular disease: The role of anti-phosphorylcholine and anti-cardiolipin antibodies. Hippokratia 2008, 12, 144.

76. Syrjälä, A.-M.H.; Ylöstalo, P.; Hartikainen, S.; Sulkava, R.; Knuuttila, M. Number of teeth and selected cardiovascular risk factors among elderly people. Gerodontology 2010, 27, 189-192. [CrossRef]

77. Touger-Decker, R. Diet, cardiovascular disease and oral health: Promoting health and reducing risk. J. Am. Dent. Assoc. 2010, 141, 167-170. [CrossRef]

78. Helkimo, E.; Carlsson, G.E.; Helkimo, M. Chewing efficiency and state of dentition. A methodologic study. Acta Odontol. Scand. 1978, 36, 33-41. [CrossRef]

79. Akeel, R.; Nilner, M.; Nilner, K. Masticatory efficiency in individuals with natural dentition. Swed. Dent. J. 1992, 16, 191-198.

80. Naka, O.; Anastassiadou, V.; Pissiotis, A. Association between functional tooth units and chewing ability in older adults: A systematic review. Gerodontology 2014, 31, 166-177. [CrossRef]

81. Tate, G.S.; Throckmorton, G.S.; Ellis, E.; Sinn, D.P. Masticatory performance, muscle activity, and occlusal force in preorthognathic surgery patients. J. Oral Maxillofac. Surg. 1994, 52, 476-482; discussion 482. [CrossRef] 
82. Fontijn-Tekamp, F.A.; Slagter, A.P.; Van Der Bilt, A.; Van 'T Hof, M.A.; Witter, D.J.; Kalk, W.; Jansen, J.A. Biting and chewing in overdentures, full dentures, and natural dentitions. J. Dent. Res. 2000, 79, 1519-1524. [CrossRef] [PubMed]

83. Kapur, K.K.; Soman, S.D. Masticatory performance and efficiency in denture wearers. J. Prosthet. Dent. 2006, 95, 407-411. [CrossRef] [PubMed]

84. Pedersen, A.M.; Bardow, A.; Jensen, S.B.; Nauntofte, B. Saliva and gastrointestinal functions of taste, mastication, swallowing and digestion. Oral Dis. 2002, 8, 117-129. [CrossRef] [PubMed]

85. Clark, J.R.; Evans, R.D. Functional occlusion: I. A review. J. Orthod. 2001, 28, 76-81. [CrossRef]

86. Furuta, M.; Yamashita, Y. Oral Health and Swallowing Problems. Curr. Phys. Med. Rehabil. Rep. 2013, 1, 216-222. [CrossRef]

87. Mishellany, A.; Woda, A.; Labas, R.; Peyron, M.-A. The challenge of mastication: Preparing a bolus suitable for deglutition. Dysphagia 2006, 21, 87-94. [CrossRef]

88. Hutton, B.; Feine, J.; Morais, J. Is there an association between edentulism and nutritional state? J. Can. Dent. Assoc. 2002, 68, 182-187.

89. Fontijn-Tekamp, F.A.; van 't Hof, M.A.; Slagter, A.P.; van Waas, M.A. The state of dentition in relation to nutrition in elderly Europeans in the SENECA Study of 1993. Eur. J. Clin. Nutr. 1996, 50 (Suppl. S2), S117-S122.

90. Greksa, L.P.; Parraga, I.M.; Clark, C.A. The dietary adequacy of edentulous older adults. J. Prosthet. Dent. 1995, 73, 142-145. [CrossRef]

91. Hung, H.-C.; Colditz, G.; Joshipura, K.J. The association between tooth loss and the self-reported intake of selected CVD-related nutrients and foods among US women. Community Dent. Oral Epidemiol. 2005, 33, 167-173. [CrossRef]

92. Takahashi, M.; Maeda, K.; Wakabayashi, H. Prevalence of sarcopenia and association with oral health-related quality of life and oral health status in older dental clinic outpatients. Geriatr. Gerontol. Int. 2018, 18, 915-921. [CrossRef] [PubMed]

93. Alvarez, J.O. Nutrition, tooth development, and dental caries. Am. J. Clin. Nutr. 1995, 61, 410S-416S. [CrossRef] [PubMed]

94. Enwonwu, C.O.; Phillips, R.S.; Falkler, W.A. Nutrition and oral infectious diseases: State of the science. Compend. Contin. Educ. Dent. 2002, 23, 431-434. [PubMed]

95. Friedlander, A.H.; Weinreb, J.; Friedlander, I.; Yagiela, J.A. Metabolic syndrome: Pathogenesis, medical care and dental implications. J. Am. Dent. Assoc. 2007, 138, 179-187. [CrossRef] [PubMed]

96. Tan, B.L.; Norhaizan, M.E.; Liew, W.-P.-P. Nutrients and Oxidative Stress: Friend or Foe? Oxid. Med. Cell. Longev. 2018, 2018. Available online: https://www.ncbi.nlm.nih.gov/pmc/articles/PMC5831951/ (accessed on 11 October 2019). [CrossRef]

97. Manzel, A.; Muller, D.N.; Hafler, D.A.; Erdman, S.E.; Linker, R.A.; Kleinewietfeld, M. Role of “Western Diet" in Inflammatory Autoimmune Diseases. Curr. Allergy Asthma Rep. 2014, 14, 404. Available online: http://link.springer.com/10.1007/s11882-013-0404-6 (accessed on 7 June 2019). [CrossRef]

98. Kang, J.; Smith, S.; Pavitt, S.; Wu, J. Association between central obesity and tooth loss in the non-obese people: Results from the continuous National Health and Nutrition Examination Survey (NHANES) 1999-2012. J. Clin. Periodontol. 2019, 46, 430-437. [CrossRef]

99. Codoñer-Franch, P.; Valls-Bellés, V.; Arilla-Codoñer, A.; Alonso-Iglesias, E. Oxidant mechanisms in childhood obesity: The link between inflammation and oxidative stress. Transl. Res. 2011, 158, 369-384. [CrossRef]

100. Hujoel, P.P.; Lingström, P. Nutrition, dental caries and periodontal disease: A narrative review. J. Clin. Periodontol. 2017, 44 (Suppl. S18), S79-S84. [CrossRef]

101. Moynihan, P.J. The role of diet and nutrition in the etiology and prevention of oral diseases. Bull. World Health Org. 2005, 83, 694-699.

102. Sheiham, A.; Steele, J.G.; Marcenes, W.; Lowe, C.; Finch, S.; Bates, C.J.; Prentice, A.; Walls, A.W. The relationship among dental status, nutrient intake, and nutritional status in older people. J. Dent. Res. 2001, 80, 408-413. [CrossRef] [PubMed]

103. Nowjack-Raymer, R.E.; Sheiham, A. Numbers of natural teeth, diet, and nutritional status in US adults. J. Dent. Res. 2007, 86, 1171-1175. [CrossRef] [PubMed]

104. Zhu, Y.; Hollis, J.H. Tooth loss and its association with dietary intake and diet quality in American adults. J. Dent. 2014, 42, 1428-1435. [CrossRef] [PubMed] 
105. Cruz-Jentoft, A.J.; Landi, F.; Topinková, E.; Michel, J.-P. Understanding sarcopenia as a geriatric syndrome. Curr. Opin. Clin. Nutr. Metab. Care 2010, 13,1-7. [CrossRef]

106. Cruz-Jentoft, A.J.; Bahat, G.; Bauer, J.; Boirie, Y.; Bruyère, O.; Cederholm, T.; Cooper, C.; Landi, F.; Rolland, Y.; Sayer, A.A.; et al. Sarcopenia: Revised European consensus on definition and diagnosis. Age Ageing 2019, 48, 16-31. [CrossRef]

107. Anker, S.D.; Morley, J.E.; von Haehling, S. Welcome to the ICD-10 code for sarcopenia. J. Cachexia Sarcopenia Muscle 2016, 7, 512-514. [CrossRef]

108. Landi, F.; Calvani, R.; Cesari, M.; Tosato, M.; Martone, A.M.; Ortolani, E.; Savera, G.; Salini, S.; Sisto, A.; Picca, A.; et al. Sarcopenia: An Overview on Current Definitions, Diagnosis and Treatment. Curr. Protein Pept. Sci. 2018, 19, 633-638. [CrossRef]

109. Liguori, I.; Russo, G.; Aran, L.; Bulli, G.; Curcio, F.; Della-Morte, D.; Gargiulo, G.; Testa, G.; Cacciatore, F.; Bonaduce, D.; et al. Sarcopenia: Assessment of disease burden and strategies to improve outcomes. Clin. Interv. Aging 2018, 13, 913-927. [CrossRef]

110. McCulloch, T.M.; Jaffe, D. Head and neck disorders affecting swallowing. GI Motil. Online 2006. Available online: https://www.nature.com/gimo/contents/pt1/full/gimo36.html (accessed on 11 October 2019).

111. Wirth, R.; Dziewas, R.; Beck, A.M.; Clavé, P.; Hamdy, S.; Heppner, H.J.; Langmore, S.; Leischker, A.H.; Martino, R.; Pluschinski, P.; et al. Oropharyngeal dysphagia in older persons-From pathophysiology to adequate intervention: A review and summary of an international expert meeting. Clin. Interv. Aging 2016, 11, 189-208. [CrossRef]

112. Robbins, J.; Bridges, A.D.; Taylor, A. Oral, pharyngeal and esophageal motor function in aging. GI Motil. Online 2006. Available online: https://www.nature.com/gimo/contents/pt1/full/gimo39.html (accessed on 11 October 2019).

113. Feng, X.; Todd, T.; Lintzenich, C.R.; Ding, J.; Carr, J.J.; Ge, Y.; Browne, J.D.; Kritchevsky, S.B.; Butler, S.G. Aging-related geniohyoid muscle atrophy is related to aspiration status in healthy older adults. J. Gerontol. Ser. A 2013, 68, 853-860. [CrossRef] [PubMed]

114. Newton, J.P.; Yemm, R.; Abel, R.W.; Menhinick, S. Changes in human jaw muscles with age and dental state. Gerodontology 1993, 10, 16-22. [CrossRef] [PubMed]

115. Wakabayashi, H.; Takahashi, R.; Watanabe, N.; Oritsu, H.; Shimizu, Y. Prevalence of skeletal muscle mass loss and its association with swallowing function after cardiovascular surgery. Nutrition 2017, 38, 70-73. [CrossRef] [PubMed]

116. Machida, N.; Tohara, H.; Hara, K.; Kumakura, A.; Wakasugi, Y.; Nakane, A.; Minakuchi, S. Effects of aging and sarcopenia on tongue pressure and jaw-opening force. Geriatr. Gerontol. Int. 2017, 17, 295-301. [CrossRef]

117. Sakai, K.; Nakayama, E.; Tohara, H.; Kodama, K.; Takehisa, T.; Takehisa, Y.; Ueda, K. Relationship between tongue strength, lip strength, and nutrition-related sarcopenia in older rehabilitation inpatients: A cross-sectional study. Clin. Interv. Aging 2017, 12, 1207-1214. [CrossRef]

118. Sporns, P.B.; Muhle, P.; Hanning, U.; Suntrup-Krueger, S.; Schwindt, W.; Eversmann, J.; Warnecke, T.; Wirth, R.; Zimmer, S.; Dziewas, R. Atrophy of Swallowing Muscles Is Associated with Severity of Dysphagia and Age in Patients with Acute Stroke. J. Am. Med. Dir. Assoc. 2017, 18, 635.e1-635.e7. [CrossRef]

119. Maeda, K.; Akagi, J. Decreased tongue pressure is associated with sarcopenia and sarcopenic dysphagia in the elderly. Dysphagia 2015, 30, 80-87. [CrossRef]

120. Butler, S.G.; Stuart, A.; Leng, X.; Wilhelm, E.; Rees, C.; Williamson, J.; Kritchevsky, S.B. The relationship of aspiration status with tongue and handgrip strength in healthy older adults. J. Gerontol. Ser. A 2011, 66, 452-458. [CrossRef]

121. Buehring, B.; Hind, J.; Fidler, E.; Krueger, D.; Binkley, N.; Robbins, J. Tongue strength is associated with jumping mechanography performance and handgrip strength but not with classic functional tests in older adults. J. Am. Geriatr. Soc. 2013, 61, 418-422. [CrossRef]

122. Tsuga, K.; Yoshikawa, M.; Oue, H.; Okazaki, Y.; Tsuchioka, H.; Maruyama, M.; Yoshida, M.; Akagawa, Y. Maximal voluntary tongue pressure is decreased in Japanese frail elderly persons. Gerodontology 2012, 29, e1078-e1085. [CrossRef] [PubMed]

123. Ertekin, C.; Aydogdu, I. Neurophysiology of swallowing. Clin. Neurophysiol. 2003, 114, 2226-2244. [CrossRef]

124. Sakai, K.; Sakuma, K. Sarcopenic Dysphagia as a New Concept. Frailty Sarcopenia Onset Dev. Clin. Chall. 2017. Available online: https://www.intechopen.com/books/frailty-and-sarcopenia-onset-development-andclinical-challenges/sarcopenic-dysphagia-as-a-new-concept (accessed on 11 October 2019). 
125. Wakabayashi, H. Presbyphagia and Sarcopenic Dysphagia: Association between Aging, Sarcopenia, and Deglutition Disorders. J. Frailty Aging 2014, 3, 97-103. [PubMed]

126. Rowlerson, A.; Raoul, G.; Daniel, Y.; Close, J.; Maurage, C.-A.; Ferri, J.; Sciote, J.J. Fiber-type differences in masseter muscle associated with different facial morphologies. Am. J. Orthod. Dentofac. Orthop. 2005, 127, 37-46. [CrossRef] [PubMed]

127. Yamaguchi, K.; Tohara, H.; Hara, K.; Nakane, A.; Kajisa, E.; Yoshimi, K.; Minakuchi, S. Relationship of aging, skeletal muscle mass, and tooth loss with masseter muscle thickness. BMC Geriatr. 2018, 18, 67. [CrossRef]

128. Ferrucci, L.; Fabbri, E. Inflammageing: Chronic inflammation in ageing, cardiovascular disease, and frailty. Nat. Rev. Cardiol. 2018, 15, 505-522. [CrossRef]

129. Yao, X.; Li, H.; Leng, S.X. Inflammation and immune system alterations in frailty. Clin. Geriatr. Med. 2011, 27, 79-87. [CrossRef]

130. Napa, K.; Baeder, A.C.; Witt, J.E.; Rayburn, S.T.; Miller, M.G.; Dallon, B.W.; Gibbs, J.L.; Wilcox, S.H.; Winden, D.R.; Smith, J.H.; et al. LPS from, P. gingivalis Negatively Alters Gingival Cell Mitochondrial Bioenergetics. Int. J. Dent. 2017, 2017. Available online: https:/www.ncbi.nlm.nih.gov/pmc/articles/ PMC5448046/ (accessed on 11 October 2019). [CrossRef]

131. Taylor, G.W.; Burt, B.A.; Becker, M.P.; Genco, R.J.; Shlossman, M.; Knowler, W.C.; Pettitt, D.J. Severe periodontitis and risk for poor glycemic control in patients with non-insulin-dependent diabetes mellitus. J. Periodontol. 1996, 67 (Suppl. S10), 1085-1093. [CrossRef]

132. Chee, B.; Park, B.; Bartold, P.M. Periodontitis and type II diabetes: A two-way relationship. Int. J. Evid. Based Healthc. 2013, 11, 317-329. [CrossRef] [PubMed]

133. Fuggle, N.R.; Smith, T.O.; Kaul, A.; Sofat, N. Hand to Mouth: A Systematic Review and Meta-Analysis of the Association between Rheumatoid Arthritis and Periodontitis. Front. Immunol. 2016, 7, 80. [CrossRef] [PubMed]

134. Beck, J.D.; Offenbacher, S.; Williams, R.; Gibbs, P.; Garcia, R. Periodontitis: A risk factor for coronary heart disease? Ann. Periodontol. 1998, 3, 127-141. [CrossRef] [PubMed]

135. D'Aiuto, F.; Nibali, L.; Parkar, M.; Patel, K.; Suvan, J.; Donos, N. Oxidative stress, systemic inflammation, and severe periodontitis. J. Dent. Res. 2010, 89, 1241-1246. [CrossRef]

136. Borges, I.; Moreira, E.A.M.; Filho, D.W.; de Oliveira, T.B.; da Silva, M.B.S.; Fröde, T.S. Proinflammatory and oxidative stress markers in patients with periodontal disease. Mediat. Inflamm. 2007, 2007, 45794. [CrossRef]

137. Horton, A.L.; Boggess, K.A.; Moss, K.L.; Beck, J.; Offenbacher, S. Periodontal disease, oxidative stress, and risk for preeclampsia. J. Periodontol. 2010, 81, 199-204. [CrossRef]

138. Bullon, P.; Cordero, M.D.; Quiles, J.L.; del Carmen Ramirez-Tortosa, M.; Gonzalez-Alonso, A.; Alfonsi, S.; García-Marín, R.; de Miguel, M.; Battino, M. Autophagy in periodontitis patients and gingival fibroblasts: Unraveling the link between chronic diseases and inflammation. BMC Med. 2012, 10, 122. [CrossRef]

139. Bullon, P.; Cordero, M.D.; Quiles, J.L.; Morillo, J.M.; del Carmen Ramirez-Tortosa, M.; Battino, M. Mitochondrial dysfunction promoted by Porphyromonas gingivalis lipopolysaccharide as a possible link between cardiovascular disease and periodontitis. Free Radic. Biol. Med. 2011, 50, 1336-1343. [CrossRef]

140. Wang, P.-L.; Ohura, K. Porphyromonas gingivalis lipopolysaccharide signaling in gingival fibroblasts-CD14 and Toll-like receptors. Crit. Rev. Oral Biol. Med. 2002, 13, 132-142. [CrossRef]

141. Andersson, P.; Hallberg, I.R.; Lorefält, B.; Unosson, M.; Renvert, S. Oral health problems in elderly rehabilitation patients. Int. J. Dent. Hyg. 2004, 2, 70-77. [CrossRef]

142. Hanne, K.; Ingelise, T.; Linda, C.; Ulrich, P.P. Oral status and the need for oral health care among patients hospitalised with acute medical conditions. J. Clin. Nurs. 2012, 21, 2851-2859. [CrossRef] [PubMed]

143. Cederholm, T.; Jensen, G.L.; Correia, M.I.T.D.; Gonzalez, M.C.; Fukushima, R.; Higashiguchi, T.; Baptista, G.; Barazzoni, R.; Blaauw, R.; Coats, A.; et al. GLIM criteria for the diagnosis of malnutrition-A consensus report from the global clinical nutrition community. Clin. Nutr. 2019, 38, 1-9. [CrossRef] [PubMed]

144. Cesari, M.; Landi, F.; Vellas, B.; Bernabei, R.; Marzetti, E. Sarcopenia and Physical Frailty: Two Sides of the Same Coin. Front. Aging Neurosci 2014, 6, 192. Available online: https://www.ncbi.nlm.nih.gov/pmc/articles/ PMC4112807/ (accessed on 5 November 2019). [CrossRef] [PubMed]

145. Cruz-Jentoft, A.J.; Kiesswetter, E.; Drey, M.; Sieber, C.C. Nutrition, frailty, and sarcopenia. Aging Clin. Exp. Res. 2017, 29, 43-48. [CrossRef] [PubMed]

146. Landi, F.; Cherubini, A.; Cesari, M.; Calvani, R.; Tosato, M.; Sisto, A.; Martone, A.M.; Bernabei, R.; Marzetti, E. Sarcopenia and frailty: From theoretical approach into clinical practice. Eur. Geriatr. Med. 2016, 7, 197-200. 
Available online: https://moh-it.pure.elsevier.com/en/publications/sarcopenia-and-frailty-from-theoreticalapproach-into-clinical-pr (accessed on 11 October 2019). [CrossRef]

147. Bauer, J.; Biolo, G.; Cederholm, T.; Cesari, M.; Cruz-Jentoft, A.J.; Morley, J.E.; Phillips, S.; Sieber, C.; Stehle, P.; Teta, D.; et al. Evidence-Based Recommendations for Optimal Dietary Protein Intake in Older People: A Position Paper from the PROT-AGE Study Group. J. Am. Med. Dir. Assoc. 2013, 14, 542-559. [CrossRef]

148. Ellis, G.; Whitehead, M.A.; O'Neill, D.; Langhorne, P.; Robinson, D. Comprehensive geriatric assessment for older adults admitted to hospital. Cochrane. Database. Syst. Rev. 2011, 7, CD006211.

149. Bollero, P.; Passarelli, P.C.; D’ Addona, A.; Pasquantonio, G.; Mancini, M.; Condò, R.; Cerroni, L. Oral management of adult patients undergoing hematopoietic stem cell transplantation. Eur. Rev. Med. Pharmacol. Sci. 2018, 22, 876-887.

150. Tonetti, M.S.; Bottenberg, P.; Conrads, G.; Eickholz, P.; Heasman, P.; Huysmans, M.-C.; López, R.; Madianos, P.; Müller, F.; Needleman, I.; et al. Dental caries and periodontal diseases in the ageing population: Call to action to protect and enhance oral health and well-being as an essential component of healthy ageing-Consensus report of group 4 of the joint EFP/ORCA workshop on the boundaries between caries and periodontal diseases. J. Clin. Periodontol. 2017, 44 (Suppl. S18), S135-S144.

151. Andreas Zenthöfer, A.; Rammelsberg, P.; Cabrera, T.; Hassel, A. Prosthetic rehabilitation of edentulism prevents malnutrition in nursing home residents. Int. J. Prosthodont. 2015, 28, 198-200. [CrossRef]

152. Volkert, D.; Beck, A.M.; Cederholm, T.; Cruz-Jentoft, A.; Goisser, S.; Hooper, L.; Kiesswetter, E.; Maggio, M.; Raynaud-Simon, A.; Sieber, C.C.; et al. ESPEN guideline on clinical nutrition and hydration in geriatrics. Clin. Nutr. 2019, 38, 10-47. [CrossRef] [PubMed]

153. Deutz, N.E.P.; Bauer, J.M.; Barazzoni, R.; Biolo, G.; Boirie, Y.; Bosy-Westphal, A.; Cederholm, T.; Cruz-Jentoft , A.; Krznariç, Z.; Nair, K.S.; et al. Protein intake and exercise for optimal muscle function with aging: Recommendations from the ESPEN Expert Group. Clin. Nutr. 2014, 33, 929-936. [CrossRef] [PubMed]

154. Johnson, M.A.; Kimlin, M.G. Vitamin D, aging, and the 2005 Dietary Guidelines for Americans. Nutr. Rev. 2006, 64, 410-421. [CrossRef] [PubMed]

155. Visser, M.; Deeg, D.J.H.; Lips, P. Longitudinal Aging Study Amsterdam. Low vitamin D and high parathyroid hormone levels as determinants of loss of muscle strength and muscle mass (sarcopenia): The Longitudinal Aging Study Amsterdam. J. Clin. Endocrinol. Metab. 2003, 88, 5766-5772. [CrossRef] [PubMed]

156. Ney, D.M.; Weiss, J.M.; Kind, A.J.H.; Robbins, J. Senescent Swallowing: Impact, Strategies, and Interventions. Nutr. Clin. Pract. 2009, 24, 395-413. [CrossRef] [PubMed]

157. Sura, L.; Madhavan, A.; Carnaby, G.; Crary, M.A. Dysphagia in the elderly: Management and nutritional considerations. Clin. Interv. Aging 2012, 7, 287-298.

158. Lutsey, P.L.; Steffen, L.M.; Stevens, J. Dietary intake and the development of the metabolic syndrome: The Atherosclerosis Risk in Communities study. Circulation 2008, 117, 754-761. [CrossRef]

159. Guideline: Sugars Intake for Adults and Children. Available online: https://apps.who.int/iris/handle/10665/ 149782 (accessed on 22 October 2019).

160. Gutteridge, J.M.C.; Halliwell, B. Antioxidants: Molecules, medicines, and myths. Biochem. Biophys. Res. Commun. 2010, 393, 561-564. [CrossRef]

161. Welch, A.A.; MacGregor, A.J.; Minihane, A.-M.; Skinner, J.; Valdes, A.A.; Spector, T.D.; Cassidy, A. Dietary fat and fatty acid profile are associated with indices of skeletal muscle mass in women aged 18-79 years. J. Nutr. 2014, 144, 327-334. [CrossRef]

162. Woelber, J.P.; Bremer, K.; Vach, K.; König, D.; Hellwig, E.; Ratka-Krüger, P.; Al-Ahmad, A.; Tennert, C. An oral health optimized diet can reduce gingival and periodontal inflammation in humans-A randomized controlled pilot study. BMC Oral Health 2016, 17, 28. [CrossRef]

163. Dupont, J.; Dedeyne, L.; Dalle, S.; Koppo, K.; Gielen, E. The role of omega-3 in the prevention and treatment of sarcopenia. Aging Clin. Exp. Res. 2019, 31, 825-836. [CrossRef] [PubMed]

164. Damanti, S.; Azzolino, D.; Roncaglione, C.; Arosio, B.; Rossi, P.; Cesari, M. Efficacy of Nutritional Interventions as Stand-Alone or Synergistic Treatments with Exercise for the Management of Sarcopenia. Nutrients 2019, 11, 1991. [CrossRef] [PubMed]

165. Dickinson, J.M.; Volpi, E.; Rasmussen, B.B. Exercise and nutrition to target protein synthesis impairments in aging skeletal muscle. Exerc. Sport Sci. Rev. 2013, 41, 216-223. [CrossRef] [PubMed] 
166. Glover, E.I.; Phillips, S.M.; Oates, B.R.; Tang, J.E.; Tarnopolsky, M.A.; Selby, A.; Smith, K.; Rennie, M.J. Immobilization induces anabolic resistance in human myofibrillar protein synthesis with low and high dose amino acid infusion. J. Physiol. 2008, 586, 6049-6061. [CrossRef]

167. Bawadi, H.A.; Khader, Y.S.; Haroun, T.F.; Al-Omari, M.; Tayyem, R.F. The association between periodontal disease, physical activity and healthy diet among adults in Jordan. J. Periodont. Res. 2011, 46, 74-81. [CrossRef]

168. Cruz-Jentoft, A.J.; Landi, F.; Schneider, S.M.; Zúñiga, C.; Arai, H.; Boirie, Y.; Chen, L.-K.; Fielding, R.A.; Martin, F.C.; Michel, J.-P.; et al. Prevalence of and interventions for sarcopenia in ageing adults: A systematic review. Report of the International Sarcopenia Initiative (EWGSOP and IWGS). Age Ageing 2014, 43, 748-759. [CrossRef]

169. Sugiyama, T.; Ohkubo, M.; Honda, Y.; Tasaka, A.; Nagasawa, K.; Ishida, R.; Sakurai, K. Effect of swallowing exercises in independent elderly. Bull. Tokyo. Dent. Coll. 2013, 54, 109-115. [CrossRef]

170. Argolo, N.; Sampaio, M.; Pinho, P.; Melo, A.; Nóbrega, A.C. Do swallowing exercises improve swallowing dynamic and quality of life in Parkinson's disease? NeuroRehabilitation 2013, 32, 949-955.

171. Kim, H.-J.; Lee, J.-Y.; Lee, E.-S.; Jung, H.-J.; Ahn, H.-J.; Kim, B.-I. Improvements in oral functions of elderly after simple oral exercise. Clin. Interv. Aging 2019, 14, 915-924. [CrossRef]

172. Park, J.S.; Oh, D.H.; Chang, M.Y.; Kim, K.M. Effects of expiratory muscle strength training on oropharyngeal dysphagia in subacute stroke patients: A randomised controlled trial. J. Oral Rehabil. 2016, 43, 364-372. [CrossRef]

173. Park, J.-S.; Oh, D.-H.; Chang, M.-Y. Effect of expiratory muscle strength training on swallowing-related muscle strength in community-dwelling elderly individuals: A randomized controlled trial. Gerodontology 2017, 34, 121-128. [CrossRef] [PubMed]

174. Park, J.S.; Hwang, N.K.; Oh, D.H.; Chang, M.Y. Effect of head lift exercise on kinematic motion of the hyolaryngeal complex and aspiration in patients with dysphagic stroke. J. Oral Rehabil. 2017, 44, 385-391. [CrossRef] [PubMed]

175. Antunes, E.B.; Lunet, N. Effects of the head lift exercise on the swallow function: A systematic review. Gerodontology 2012, 29, 247-257. [CrossRef] [PubMed]

176. Steele, C.M.; Bayley, M.T.; Peladeau-Pigeon, M.; Nagy, A.; Namasivayam, A.M.; Stokely, S.L.; Wolkin, T. A Randomized Trial Comparing Two Tongue-Pressure Resistance Training Protocols for Post-Stroke Dysphagia. Dysphagia 2016, 31, 452-461. [CrossRef] [PubMed]

177. Kim, H.D.; Choi, J.B.; Yoo, S.J.; Chang, M.Y.; Lee, S.W.; Park, J.S. Tongue-to-palate resistance training improves tongue strength and oropharyngeal swallowing function in subacute stroke survivors with dysphagia. J. Oral Rehabil. 2017, 44, 59-64. [CrossRef] [PubMed]

178. Yeates, E.M.; Molfenter, S.M.; Steele, C.M. Improvements in tongue strength and pressure-generation precision following a tongue-pressure training protocol in older individuals with dysphagia: Three case reports. Clin. Interv. Aging 2008, 3, 735-747. [CrossRef]

179. Robbins, J.; Gangnon, R.E.; Theis, S.M.; Kays, S.A.; Hewitt, A.L.; Hind, J.A. The effects of lingual exercise on swallowing in older adults. J. Am. Geriatr. Soc. 2005, 53, 1483-1489. [CrossRef] 